Western North American Naturalist 70(1), (C) 2010, pp. 19-25

\title{
LARGE-SCALE EFFECTS ON BIRD ASSEMBLAGES IN DESERT GRASSLANDS
}

\author{
Giselle Block ${ }^{1}$ and Michael L. Morrison ${ }^{2,3}$
}

\begin{abstract}
During winter 1996-1997 and summer 1997, we surveyed birds at 26 study sites in desert grasslands of Arizona and New Mexico to determine tolerance of birds to variability in plant composition and structure. The relationship between bird abundance and vegetative characteristics might be an important consideration in the development of management and restoration plans. Of the 49 bird species we observed, we examined 13 and 16 species in detail for winter and summer seasons, respectively. A noticeable shift in species composition occurred between $3 \%$ and $10 \%$ woody plant cover. During winter, Chestnut-collared Longspurs (Calcarius ornatus) and Horned Larks (Eremophila alpestris) showed significant positive relationships with grass cover and negative relationships with woody plant cover, occurring in greatest numbers where woody cover was $<1 \%$. The richness of sparrow species during winter was highest among sites with $6 \%$ to $15 \%$ woody plant cover. In addition to showing significant positive relationships with woody cover, Vesper Sparrows (Pooecetes gramineus), Black-throated Sparrows (Amphispiza bilineata), Brewer’s Sparrows (Spizella breweri), and Chipping Sparrows (S. passerina) showed significant positive relationships with shrub species richness. Our results showed that reductions of woody plant cover below $3 \%$ in combination with the presence of native grasses could substantially enhance the presence of several bird species. Maintenance of woody cover between $6 \%$ and $15 \%$ could increase use by a suite of other species, especially wintering sparrows.
\end{abstract}

Key words: desert grasslands, bird assemblages, habitat restoration, Arizona, New Mexico.

Over the past approximately 150 years, desert grasslands of the southwestern United States have experienced a continual shift from grasslands with little woody cover to shrub- and tree-dominated landscapes (Hastings and Turner 1965, Bahre 1995, Burgess 1995). This shift has reduced available habitat for grassland-associated birds and likely contributes to range-wide declines in population numbers (Bock and Webb 1984, Bock and Bock 1988, Hall et al. 2002).

Bird species characteristic of desert grasslands that show negative population responses to invasions by woody species include Grasshopper Sparrow (scientific binomials in Table 1), Chestnut-collared Longspur, and Horned Lark (Bock and Bock 1988, 1992). However, knowledge of the specific amounts of vegetation alteration that result in major shifts in bird species composition both within and between seasons is lacking, especially at large spatial scales $\left(>1000 \mathrm{~km}^{2}\right)$. Thus, we examined how individual bird species and species assemblages distributed themselves seasonally across a vegetation gradient in desert grasslands of southeastern
Arizona and southwestern New Mexico. Knowledge of the range of habitat measures within which species and assemblages occur seasonally in desert grasslands will help managers better guide development of specific management and restoration goals. Although our study was limited to one year and cannot evaluate potential interannual variation, our data quantify predominant bird- habitat relationships in this ecosystem across a relatively large spatial scale. Future studies can use our data to monitor longterm changes in bird assemblage structure and composition.

\section{StUdy AREA}

We worked in desert grasslands of the San Simon and San Bernardino valleys of Cochise County, Arizona, and the Animas Valley of Hidalgo County, New Mexico. Vegetation in the valleys ranged from grassland with little or no woody cover to areas where woody plants, such as mesquite (Prosopsis spp.), dominated. The region is characterized by gently sloping, dissected alluvial fans and

${ }^{1}$ U.S. Fish and Wildlife Service, San Pablo Bay National Wildlife Refuge, 7715 Lakeville Highway, Petaluma, CA 94954.
${ }^{2}$ Department of Wildlife and Fisheries Sciences, Texas A\&M University, College Station, TX 77843-2258.

${ }^{3}$ Corresponding author. E-mail: mlmorrison@ag.tamu.edu 
TABLE 1. Observation frequency (per study site, $n=26$ ) of birds in desert grasslands of southeastern Arizona and southwestern New Mexico, winter 1996-1997 and summer 1997. Presented in order of decreasing abundance in winter.

\begin{tabular}{|c|c|c|c|}
\hline Common name & Scientific name & Winter & Summer \\
\hline Grasshopper Sparrow & Ammodramus savannarum & 89 & 54 \\
\hline Eastern Meadowlark & Sturnella magna & 81 & 100 \\
\hline Vesper Sparrow & Pooecetes gramineus & 70 & \\
\hline Horned Lark & Eremophila alpestris & 69 & 58 \\
\hline Chestnut-collared Longspur & Calcarius ornatus & 54 & \\
\hline Mourning Dove & Zenaida macroura & 46 & 58 \\
\hline Cactus Wren & Campylorhynchus brunneicapillus & 46 & 54 \\
\hline Black-throated Sparrow & Amphispiza bilineata & 38 & 58 \\
\hline Loggerhead Shrike & Lanius ludovicianus & 35 & 54 \\
\hline Brewer's Sparrow & Spizella breweri & 27 & \\
\hline Chipping Sparrow & Spizella passerina & 27 & \\
\hline Say's Phoebe & Sayornis saya & 27 & \\
\hline Scaled Quail & Callipepla squamata & 23 & 65 \\
\hline Savannah Sparrow & Passerculus sandwichensis & 23 & \\
\hline Black-tailed Gnatcatcher & Polioptila melanura & 19 & 11 \\
\hline White-crowned Sparrow & Zonotrichia leucophrys & 19 & \\
\hline Baird's Sparrow & Ammodramus bairdii & 15 & \\
\hline Cassin’s Sparrow & Aimophila cassinii & 11 & 42 \\
\hline Rufous-crowned Sparrow & Aimophila ruficeps & 11 & 8 \\
\hline Mountain Bluebird & Sialia currucoides & 11 & \\
\hline Killdeer & Charadrius vociferus & 8 & 19 \\
\hline House Finch & Carpodacus mexicanus & 8 & \\
\hline Field Sparrow & Spizella pusilla & 8 & \\
\hline Northern Flicker & Colaptes auratus & 8 & \\
\hline American Pipit & Anthus rubescens & 8 & \\
\hline Curve-billed Thrasher & Toxostoma curvirostre & 8 & \\
\hline Northern Mockingbird & Mimus polyglottos & 4 & 46 \\
\hline Lark Sparrow & Chondestes grammacus & 4 & 15 \\
\hline Rufous-winged Sparrow & Aimophila carpalis & 4 & 4 \\
\hline Rock Wren & Salpinctes obsoletus & 4 & \\
\hline Gambel's Quail & Callipepla gambelii & 2 & 38 \\
\hline Verdin & Auriparus flaviceps & 2 & 4 \\
\hline American Goldfinch & Spinus tristis & 2 & \\
\hline Lark Bunting & Calamospiza melanocorys & & 65 \\
\hline Kingbird spp. & Tyrannus spp. & & 46 \\
\hline Blue Grosbeak & Passerina caerulea & & 42 \\
\hline California Towhee & Pipilo crissalis & & 31 \\
\hline Ash-throated Flycatcher & Myiarchus cinerascens & & 27 \\
\hline Botteri's Sparrow & Aimophila botterii & & 19 \\
\hline Northern Cardinal & Cardinalis cardinalis & & 15 \\
\hline Greater Roadrunner & Geococcyx californianus & & 12 \\
\hline Bell's Vireo & Vireo bellii & & 8 \\
\hline Pyrruloxia & Cardinalis sinuatus & & 8 \\
\hline Empidonax spp. & Empidonax spp. & & 8 \\
\hline Brown-crested Flycatcher & Myiarchus tyrannulus & & 4 \\
\hline Brown-headed Cowbird & Molothrus ater & & 4 \\
\hline Scott's Oriole & Icterus parisorum & & 4 \\
\hline Lucy's Warbler & Vermivora luciae & & 4 \\
\hline Great Blue Heron & Ardea herodias & & 4 \\
\hline
\end{tabular}

nearly level, broad valley floors. Elevation of valley floors ranged from 1350 to $1450 \mathrm{~m}$. Precipitation ranges from approximately 20-40 $\mathrm{cm}$ annually and is primarily distributed from late July to September (Van Devender 1995). Average annual temperatures range from approximately 14 to $17{ }^{\circ} \mathrm{C}$. Livestock grazing is the dominant land use within the region.

\section{METHODS}

\section{Survey Sites}

During August 1996, we established twentyeight 1-km survey transects, which we treated as independent sample sites; 22 sites were in Arizona and 6 in New Mexico (site coordinates in appendix A of Downard 1998). Although we 
randomly assigned the starting point and orientation of transects, we systematically chose the general sampling sites to reflect our goal of sampling the observable range of desert grassland environments within the region. Additionally, our selection of sampling sites was constrained, in part, by the ability to obtain permission to access specific landholdings. Based on these criteria, we selected 6 sites with $<1 \%$ woody cover and a mixture of native grasses, 7 sites with varying levels of woody cover $(0 \%-8 \%)$ but dominated $(>50 \%)$ by one grass species, 7 sites with woody plant cover between $5 \%$ and $10 \%$ and a diversity of native grass and woody plant species, and 8 sites with woody plant cover $>10 \%$ but supporting grass cover at $>20 \%$. We removed 2 sites in Arizona from the analysis because of an unexpected fire.

We established sites in areas with uniform elevation and vegetation by examining topographic maps and visually assessing the landscape (GIS layers were not available to us at that time). We placed transects $>500 \mathrm{~m}$ apart to minimize interdependence of samples and $>200 \mathrm{~m}$ from riparian corridors to avoid misinterpretation of bird-habitat relationships within grasslands.

We walked at a rate of $1.0-1.5 \mathrm{~km} \cdot$ hour $^{-1}$ and counted birds during November-February 1996/97 (winter) between 07:00 and 12:00 and May-August 1997 (summer) between 04:30 and 07:00 using variable-width transects (Emlen 1971). We surveyed each site 5 times each season. During summer, we excluded individuals identified by sight alone to minimize bias associated with differences in vegetation height and cover between transects. We present winter and summer bird assemblages as the average frequency of occurrence of each species across the 26 sites analyzed (Table 1).

\section{Vegetation}

We used line-point intercepts (Elzinga et al. 1998:182) to sample horizontal and vertical vegetation attributes at each study site (transect) during September-November 1996. In May 1997, we resampled vegetation from a subset of the study sites to determine if significant seasonal differences existed. We measured vegetation at $1-\mathrm{m}$ intervals along 10 randomly placed, $40-\mathrm{m}$ transects oriented perpendicular to each 1-km survey transect, for a total of 400 points per study site. Horizontal measurements were percent cover of bare ground, litter, pebble $(<5 \mathrm{~cm})$, cobble $(>5 \mathrm{~cm})$, grass, forbs, shrubs, trees, and total woody plants (shrubs, trees, and cacti combined). Vertical measurements were height of grasses ( $15-\mathrm{cm}$ intervals) and woody plants $(0.5-\mathrm{m}$ intervals $)$ that intercepted a measuring stick. We used the average frequency of each grass and woody height class to determine vertical height diversity and grass species diversity, using the equation from Shannon and Weaver (1949:17). We recorded grass, shrub, and tree species richness (i.e., number of species) at each study site and identified all plants to species. Botanical nomenclature follows Chase (1971), Stubbendieck et al. (1992), and McClaren and Van Devender (1995).

\section{Bird-Habitat Relationships}

Data for each bird species at each site were pooled and divided by the number of surveys to calculate an index of mean observation rate per season (Swengel 1996). Using Spearman's rank correlation, we examined bivariate correlations between observation rates and vegetation variables (i.e., structure, species richness, individual plant species). Correlations were considered statistically significant at $P<0.01$ because of the multiple comparisons. To allow for valid statistical inferences on bird-habitat relationships, we only analyzed bird species observed at $>20 \%$ of the study sites (Naranjo and Raitt 1993). Multivariate analyses (e.g., principal component analysis, and multiple regression) of our data set were explored by Downard (1998), but results did not enhance interpretation of the univariate and graphical results.

\section{RESULTS}

\section{Vegetation Characteristics}

Across our 26 sites, grass cover ranged from $21 \%$ to $69 \%$ during winter $(\bar{x}=48, \mathrm{SD}=12.0)$ and from $13 \%$ to $69 \%$ during summer $(\bar{x}=45$, $\mathrm{SD}=15.6$ ). The percentage of woody cover ranged from $0 \%$ to $16 \%$ during winter $(\bar{x}=6$, $\mathrm{SD}=5.4$ ) and from $0 \%$ to $14 \%$ during summer $(\bar{x}=5, \mathrm{SD}=4.9)$. Grass species diversity ranged from 0.1 to 1.4 during winter $(\bar{x}=0.7$, $\mathrm{SD}=0.39)$ and from 0.1 to 1.5 during summer $(\bar{x}=0.7, \mathrm{SD}=0.40)$. Shrub species richness ranged from 0 to 9 during winter $(\bar{x}=2.4$, SD $=2.76)$ and from 0 to 6 during summer $(\bar{x}=$ $1.8, \mathrm{SD}=1.70$ ), and tree species richness ranged from 0 to 3 during both winter $(\bar{x}=1.2$, $\mathrm{SD}=0.83)$ and summer $(\bar{x}=1.1, \mathrm{SD}=0.89)$. 


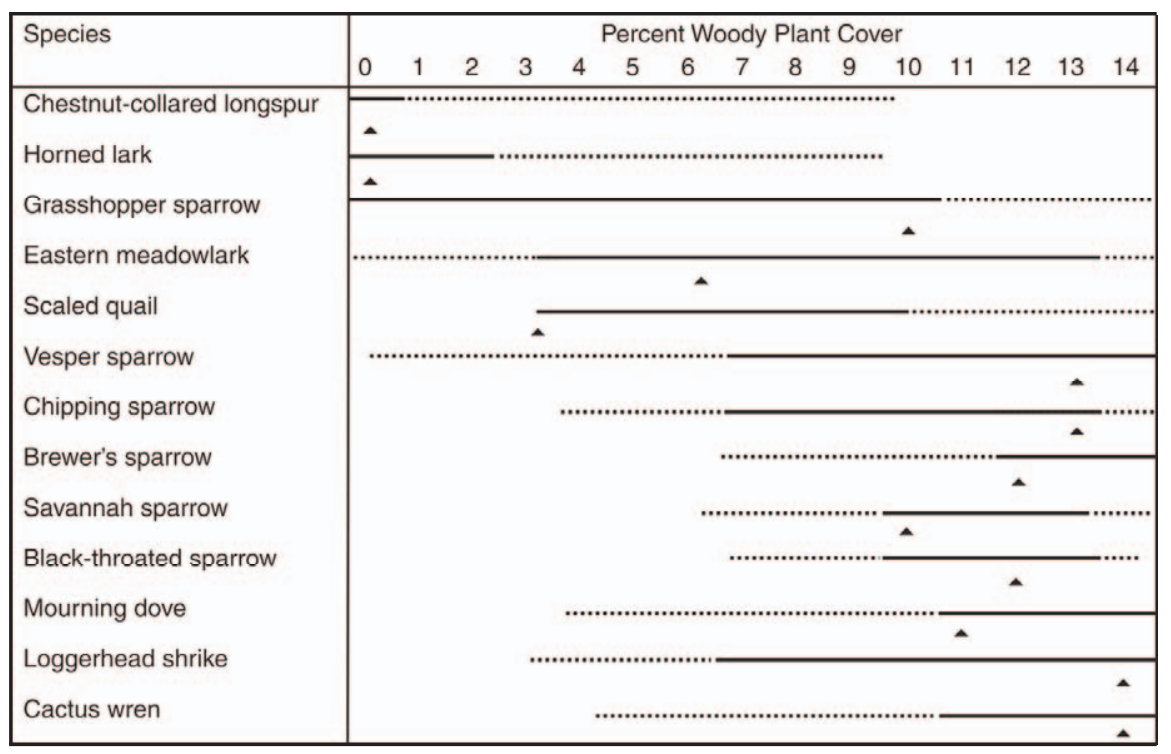

Fig. 1. Distribution of common bird species relative to woody plant cover (\%) in desert grasslands of Arizona and New Mexico, winter 1996-1997. Bold lines represent 75\%, and dotted lines 25\%, of all individuals counted. Triangles indicate maximum observation rates.

We identified 19 woody plant species, with snakeweed (Gutierrezia sarothrae; present at 16 of 26 sites) and mesquite ( 15 of 26 sites) the most common species. We observed 33 grass species, of which the most common were red sprangletop (Leptochloa filiformes; present at 22 of 26 sites), tobosagrass (Pleuraphis mutica; 18 of 26 sites), sideoats grama (Bouteloua curtipendula; 17 of 26 sites), black grama (B. eriopoda), and blue grama (B. gracilis; 16 of 26 sites). Among these commonly observed species, only red sprangletop was nonnative to these grasslands.

\section{Bird-Habitat Relationships in Winter}

We observed 33 bird species during winter (Table 1), of which 11 (33\%) were known winter migrants into the region (Rising 1996, Kaufman 2000). Sparrows comprised $64 \%$ (7 of 11) of the migrant species. Grasshopper Sparrow, Eastern Meadowlark, Horned Lark, and Vesper Sparrow were the most widely occurring species across the study sites. We used 13 of the wintering species in subsequent analyses (see below).

Of the 13 species we examined, 10 showed significant correlations with woody plant cover. Species showing no relationship were Grasshopper Sparrow, Scaled Quail, and Eastern Meadowlark. Grasshopper Sparrow was significantly and positively related only to silver beardgrass (Andropogon saccharoides; $r=0.51$ ) and Scaled Quail only to bare ground $(r=0.51)$. Species showing the strongest positive relationships with woody cover were Vesper Sparrow $(r=0.74)$, Mourning Dove $(r=0.72)$, Blackthroated Sparrow $(r=0.75)$, and Cactus Wren $(r=0.79)$. Horned Lark $(r=-0.86)$ and Chestnut-collard Longspur $(r=-0.73)$ showed a significant negative relationship with woody cover; the longspur was the only species showing a significant positive relationship with grass cover $(r=0.53)$. Vesper Sparrow was positively associated $(r=0.53)$ with grass species diversity. Vesper Sparrow, Black-throated Sparrow, Brewer's Sparrow, and Chipping Sparrow all showed significant positive relationships (all $r$ $>0.6$ ) with shrub species richness.

Because woody cover explained much of the variability in vegetation characteristics between sites and was significantly related to observation rates of most species, we examined in more detail the distribution of bird species relative to woody cover (Fig. 1). More than $75 \%$ of our observations of Chestnut-collared Longspur and Horned Lark were at sites with $<3 \%$ woody cover, and the highest observation rates occurred at sites without woody cover. Observation rates of Grasshopper Sparrow and Eastern Meadowlark varied little among differing levels of woody cover. Scaled Quail were 


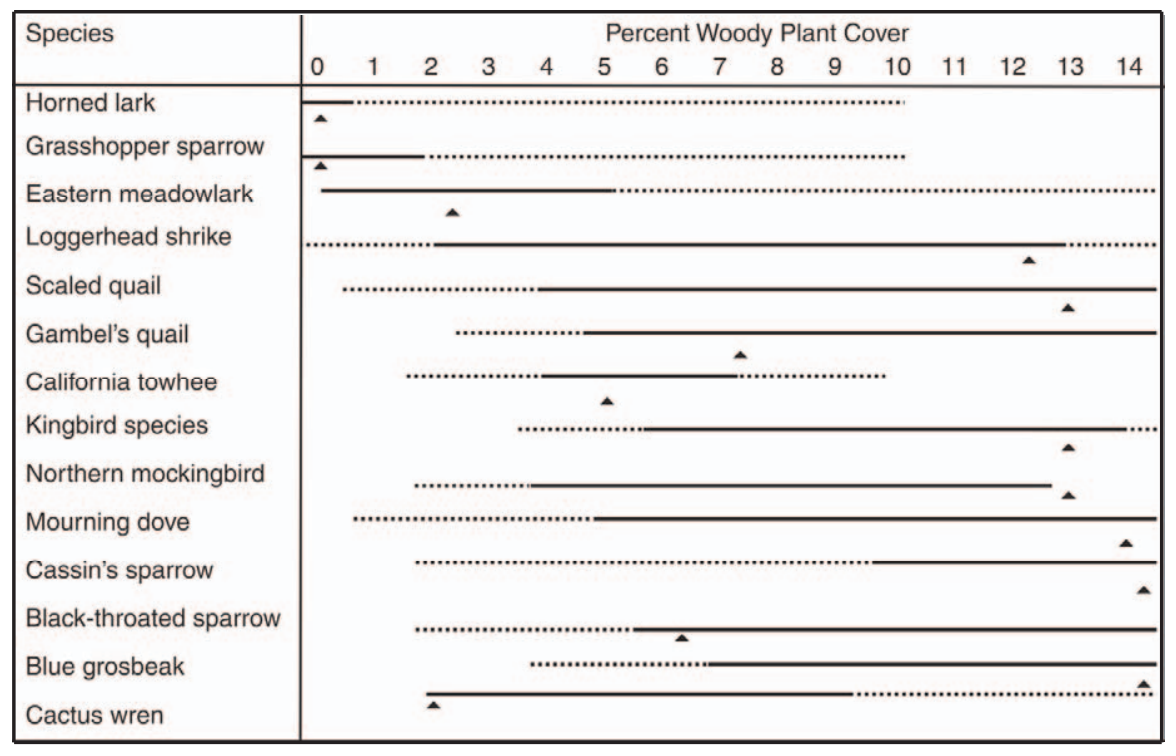

Fig. 2. Distribution of common bird species relative to woody plant cover $(\%)$ in desert grasslands of Arizona and New Mexico, summer 1997. Bold lines represent $75 \%$, and dotted lines $25 \%$, of all individuals counted. Triangles indicate maximum observation rates.

most often seen at $3.5 \%$ woody plant cover, and observation rates decreased as woody cover increased. Seventy-five percent of Chipping Sparrow, Brewer's Sparrow, Mourning Dove, and Cactus Wren observations occurred at sites with $>11 \%$ woody cover; and $75 \%$ of Savannah Sparrow and Black-throated Sparrow were observed between $10 \%$ and $14 \%$ woody cover. Maximum observation rates for all sparrow species occurred between 10\% and 13\% woody cover. Bird species richness was lowest among sites with $<3 \%$ woody cover and greatest among sites with $6 \%$ to $10 \%$ woody cover.

\section{Bird-Habitat Relationships in Summer}

We detected 33 bird species in summer (Table 1), of which 9 are known summer migrants to the region. Eastern Meadowlark, Lark Bunting, Scaled Quail, Black-throated Sparrow, and Mourning Dove were the most common species across our study sites. We used 16 species in subsequent analyses.

Horned Lark $(r=-0.82)$, Grasshopper Sparrow $(r=-0.73)$, and Eastern Meadowlark $(r=-0.54)$ were the only species that showed a negative correlation with woody cover. Horned Lark $(r=0.70)$ and Grasshopper Sparrow $(r=0.67)$ showed a positive correlation with grass cover. Positive correlations with woody cover were shown for
Black-throated Sparrow $(r=0.76)$, Blue Grosbeak $(r=0.76)$, kingbird species $(r=0.68)$, Mourning Dove $(r=0.67)$, Scaled Quail $(r$ $=0.65)$, Cassin's Sparrow $(r=0.64)$, Gambel's Quail $(r=0.55)$, and Cactus Wren $(r=$ $0.56)$. Only Black-throated Sparrow $(r=-0.63)$ and Scaled Quail $(r=-0.72)$ showed significant negative association with grass cover. No species were significantly associated with grass species diversity. Black-throated Sparrow, Scaled Quail, Cactus Wren, Blue Grosbeak, kingbird species, California Towhee, and Ash-throated Flycatcher showed significant positive (all $r>0.55$ ) relationships with shrub species richness. Approximately $75 \%$ of the significant correlations with specific plant species were with mesquite, snakeweed, and cactus species.

Observation rates across levels of woody cover ranging from $0 \%$ to $15 \%$ showed the range of response bird species exhibited during summer (Fig. 2). Horned Lark and Grasshopper Sparrow showed strong response to woody cover, with $75 \%$ of observations made at $<2 \%$ woody cover; these species were absent at sites with $>10 \%$ woody cover. Eastern Meadowlark, Loggerhead Shrike, Scaled Quail, and Mourning Dove were the most widely distributed species across levels of woody cover. More than $75 \%$ of our observations of Gambel's 
Quail, kingbird species, Cassin's Sparrow, Black-throated Sparrow, and Blue Grosbeak occurred at $>5 \%$ woody cover; our highest observation rates of these species occurred at sites with $>12 \%$ woody cover.

\section{Between-Season Comparison}

Among resident species, Grasshopper Sparrow, Scaled Quail, and Gambel's Quail showed the largest between-season shift in the number of sites occupied (Table 1). Both quail species showed a wider distribution in summer, whereas the Grasshopper Sparrow showed a wider winter distribution. The remaining resident species, including the relatively abundant Black-throated Sparrow, showed similar distributions between seasons.

\section{Discussion}

Within our study region, woody plant cover appeared to strongly influence the occurrence of bird species on desert grasslands during both winter and summer. Grasshopper Sparrow (summer) and Horned Lark (summer and winter) only inhabited sites with $<10 \%$ woody cover and were most abundant in areas with $<3 \%$ woody cover. Among resident species, Grasshopper Sparrow showed the largest between-season shift in distribution relative to vegetative characteristics. Bock et al. (1984) showed that Grasshopper Sparrow exhibited minimal between-season population shifts, although in desert grasslands of Arizona, the mean number of individuals observed more than doubled between summer and fall sampling (Bock and Bock 1992). Gordon (2000) showed that sparrow species, including Grasshopper Sparrow, moved widely during winter, which resulted in changing local abundances. In contrast, Horned Lark numbers remained relatively stable between seasons, which highlights one of the species-specific differences in distribution in the grasslands we studied. Although Lark Bunting was recorded during our summer season, we found no evidence of breeding; this species was apparently migrating through our study region.

Similar to Horned Lark and Grasshopper Sparrow, Chestnut-collared Longspur is considered a sensitive grassland bird species that is experiencing range-wide population declines (Brown and Davis 1994, Rising 1996, Sauer et al. 2001). We observed Chestnut-collared
Longspur at sites with $<10 \%$ woody cover, and they were most abundant at sites with $<1 \%$ woody cover. Although this species is reported to occur in small flocks during winter (Rising 1996), we observed flocks of >50 individuals during winter (unpublished data), especially in areas with $<1 \%$ woody cover and dominated by blue grama grass (Animas Valley, $\mathrm{NM}$ ). As woody plant cover reached approximately $6 \%$, a wide range of other species occurred, including several species of wintering sparrows. Within the range of $9 \%$ to $13 \%$ woody cover, observation rates of sparrow species during winter were greatest. Species that were uncommon during our study generally occur in more xeric environments with higher levels of woody plant cover. These include species such as Verdin, Black-tailed Gnatcatcher, Curve-billed Thrasher, Pyrruloxia, Scott's Oriole, and Northern Cardinal (Bock et al. 1984, Bock and Bock 1988, 1992).

Specific changes in vegetation structure in desert grasslands on a large spatial scale can substantially affect the resulting range of bird assemblages. Consequently, thresholds in woody plant cover that affect bird species composition can be used to design and monitor restoration activities, such as tree and brush removal. Within our study areas, reduction of woody cover below $2 \%$ would likely enhance use by Grasshopper Sparrow, Horned Lark, and longspurs. Management of woody cover between $6 \%$ and $15 \%$ would likely increase use by many sparrow species, especially during winter. Maintaining woody cover above $15 \%$ in this region would primarily enhance habitat for species, such as Verdin, orioles, Cactus Wren, and Blue Grosbeak, that showed an inverse relationship with native grass cover and hence desert grassland. Because species' associations can vary widely between seasons, bird populations should be monitored seasonally following restoration. Management recommendations specific to our study locations were detailed in Downard (1998).

We rarely detected Baird's Sparrow and did not detect Sprague's Pipit (Anthus rubescens) during our study. These species are considered typical of desert grasslands (winter) and are experiencing range-wide declines due to habitat degradation and loss (Sauer et al. 1995, Rising 1996). Our study area encompassed the northwestern edge of the wintering range of both species. Habitat degradation in the 
remaining grasslands in our study region is primarily due to overgrazing, invasive plants, and increasing woody cover. Despite these concerns, conservation, enhancement, and restoration of desert grassland is possible through the active participation of many ranchers and landowners in projects and partnerships that support land and wildlife conservation (e.g., Malpais Borderlands Group)

\section{ACKNOWLEDGMENTS}

Our work was supported by the USDA Forest Service, Rocky Mountain Research Station; the Arizona Game and Fish Department; and the Arid Lands Consortium. We thank P. Krausman and S. Hopp, University of Arizona, for their guidance; M. Bucci, J. White, and M. Sureda for field assistance; members of the Malpais Borderlands Group and other ranchers in the region for their historical perspective, knowledge of desert grasslands, and generous logistical support; and G. Block and P. Kenison for their support. Two anonymous reviewers improved our manuscript.

\section{Literature Cited}

BaHRE, C.J. 1995. Human impacts on the grasslands of southeastern Arizona. Pages 230-264 in M.P. McClaren and T.R. Van Devender, editors, The desert grassland. University of Arizona Press, Tucson, AZ.

BocK, C.E., AND J.H. BocK. 1988. Grassland birds in southeastern Arizona: impacts of fire, grazing, and alien vegetation. ICBP Technical Publication 7:43-58.

1992. Response of birds to wildfire in native versus exotic Arizona grassland. Southwestern Naturalist 37:73-81.

Bock, C.E., J.H. Bock, W.R. Kenney, and V.M. HawTHORNE. 1984. Response of birds, rodents, and vegetation to livestock exclosure in a semi-desert grassland site. Journal of Range Management 37:239-242.

Bock, C.E., AND B. WebB. 1984. Birds as grazing indicator species in southeastern Arizona. Journal of Wildlife Management 48:1045-1049.

Brown, D.E., AND R. Davis. 1994. One hundred years of vicissitude: terrestrial bird and mammal distribution changes in the American Southwest, 1890-1990. Pages 231-244 in Biodiversity and management of the Madrean Archipelago: the sky islands of southwestern United States and northwestern Mexico. General Technical Report RM-GTR-264, USDA Forest Service, Rocky Mountain Forest and Range Experiment Station, Fort Collins, CO.

BurgESS, T.L. 1995. Desert grassland, mixed shrub savanna, shrub steppe, or semidesert scrub? The dilemma of coexisting growth forms. Pages 31-67 in M.P.
McClaren and T.R. Van Devender, editors, The desert grassland. University of Arizona Press, Tucson, AZ.

Chase, A. 1971. Manual of the grasses of the United States. 2nd edition. Dover Publications, New York, NY.

DownarD, G.T. 1998. Bird-habitat relationships along a vegetation gradient in desert grasslands of the Southwest. Master's thesis, University of Arizona, Tucson, AZ.

Elzinga, C.L., D.W. SALZER, and J.W. Willoughby [EDITORS]. 1998. Measuring and monitoring plant populations. Bureau of Land Management, Denver, CO.

Emlen, J.T. 1971. Population densities of birds derived from transect counts. Auk 88:323-342.

GoRDOn, C.E. 2000. Movement patterns of wintering grassland sparrows in Arizona. Auk 117:748-759.

Hall, L.S., M.L. Morrison, L.L. Christoferson, J. MaRTin, C.E. Bock, And T.R. STRong. 2002. Bird populations in riparian areas of southeastern Arizona in 1985-86 and 1994-95. Western North American Naturalist 62:370-376.

Hastings, J.R., And R.M. Turner. 1965. The changing mile: an ecological study of the vegetation change with time in the lower mile of an arid and semiarid region. University of Arizona Press, Tucson, AZ.

Kaufman, K. 2000. Birds of North America. Houghton Mifflin Company, New York, NY.

McClaren, M.P., and T.R. Van Devender [editors]. 1995. The desert grassland. University of Arizona Press, Tucson, AZ.

Naranjo, L.G., and R.J. Raitt. 1993. Breeding bird distribution in Chihuahuan desert habitats. Southwestern Naturalist 38:43-51.

Rising, J.D. 1996. A guide to the identification and natural history of the sparrows of the United States and Canada. Academic Press, New York, NY.

Sauer, J.R., J.E. Hines, and J. Fallon. 2001. The North American breeding bird survey results and analysis 1966-2000. Version 2001.2. Patuxent Wildlife Research Center, Laurel, MD.

Sauer, J.R., G.W. Pendleton, and S. Orsillo. 1995. Mapping of bird distributions from point count surveys. Pages 151-160 in C.J. Ralph, J.R. Sauer, and S. Droege, editors, Monitoring bird populations by point counts. General Technical Report PSW-GTR-149, USDA Forest Service, Pacific Southwest Research Station.

Shannon, C., AND W. Weaver. 1949. The mathematical theory of communication. University of Illinois Press, Urbana, IL.

Stubbendieck, J., S.L. Hatch, and C.H. Butterfield. 1992. North American range plants. 4th edition. University of Nebraska Press, Lincoln, NE.

Swengel, S.R. 1996. Management responses of three species of declining sparrows in tallgrass prairie. Bird Conservation International 6:241-253.

VAN DEVEnder, T.R. 1995. Desert grassland history: changing climates, evolution, biogeography, and community dynamics. Pages 68-99 in M.P. McClaren and T.R. Van Devender, editors, The desert grassland. University of Arizona Press, Tucson, AZ.

Received 13 January 2009 Accepted 2 October 2009 